\title{
PENERAPAN MODEL PEMBELAJARAN KOOPERATIF TIPE JIGSAW UNTUK MENINGKATKAN HASIL BELAJAR ILMU PENGETAHUAN SOSIAL SISWA KELAS V
}

\author{
I Made Citra Wibawa ${ }^{1, *}$, I Made Hendra Sukmayasa ${ }^{2}$ \\ 1 Jurusan Pendidikan Guru Sekolah Dasar. Universitas Pendidikan Ganesha, Indonesia \\ 2 Jurusan Pendidikan Guru Sekolah Dasar. Universitas Pendidikan Ganesha, Indonesia
}

\begin{abstract}
Abstrak
Tujuan dari penelitian adalah untuk meningkatkan hasil belajar siswa setelah penerapan model pembelajaran kooperatif tipe Jigsaw dalam pembelajaran Ilmu Pengetahuan Sosial di kelas V semester II SD No. 2 Petandakan tahun pelajaran 2010/2011. Jenis penelitian ini adalah penelitian tindakan kelas dilaksanakan dalam tiga siklus. Data tentang hasil belajar siswa menggunakan tes hasil belajar. Hasil penelitian dianalisis dengan metoda deskriptif kuantitatif. Hasil penelitian siklus I diperoleh nilai rata-rata hasil belajar siswa 62,64 dengan ketuntasan belajar 71,43\%. Nilai rata-rata hasil belajar siswa pada siklus II yaitu 66,93 dengan ketuntasan belajar $78,57 \%$. Sedangkan pada siklus III nilai rata-rata hasil belajar siswa 74,07 dengan ketuntasan belajar 100\%. Dengan diberikan bimbingan secara intensif maka tampak peningkatan hasil belajar siswa sebesar 11,43 dan ketuntasan belajarnya pun meningkat sebesar $28,57 \%$.
\end{abstract}

\author{
Keywords: \\ jigsaw, hasil belajar IPS
}

\section{Pendahuluan}

Dalam pelaksanaan pembelajaran di kelas guru berusaha menciptakan situasi dan kondisi yang sesuai dengan kebutuhan siswa agar siswa dapat mengikuti proses pembelajaran dengan baik, sehingga materi-materi yang disampaikan oleh guru dapat diterima dan dipahami oleh siswa.Salah satu mata pelajaran yang ada di sekolah dasar kelas V semester II SD No. 2 Petandakan yang materinya sulit dipahami oleh siswa adalah mata pelajaran Ilmu Pengetahuan Sosial. Hal tersebut dikarenakan guru hanya menggunakan metode ceramah dalam pelaksanaan pembelajaran sehingga siswa menjadi kurang bersemangat dalam mengikuti pembelajaran yang diberikan oleh guru.

Pembelajaran yang dapat diterapkan oleh guru sekolah dasar kelas V semester II SD No. 2 Petandakan agar siswanya dapat bersemangat dalam mengikuti pembelajaran adalah dengan menerapkan model pembelajaran kooperatif. Menurut Arnyana (2007) pembelajaran kooperatif merupakan strategi pembelajaran dalam kelompok kecil yang bekerja bersama-sama untuk memaksimalkan penguasaan tentang apa yang dipelajari siswa. Dalam pembelajaran kooperatif terjadi proses saling membantu di antara anggota kelompok.

Menurut Slavin (dalam Trianto, 2009) menyatakan bahwa pembelajaran kooperatif bukanlah sesuatu yang baru. Sebab guru secara tidak langsung menggunakan pembelajaran tersebut dalam kesehariannya mengajar di kelas ataupun saat bekerja di laboratorium.Berdasarkan pendapat para ahli di atas maka dapat disimpulkan bahwa pembelajaran kooperatif adalah model pembelajaran pada kelompok-kelompok kecil yang menuntut kerjasama dan tanggung jawab siswa dalam menguasai materi yang dipelajari sehingga tujuan pembelajaran dapat tercapai secara maksimal.

Namun demikian, berdasarkan hasil pengamatan di Sekolah Dasar kelas V semester II SD No. 2 Petandakan menunjukan bahwa pelaksanaan pembelajaran kooperatif kurang maksimal. Hal itu terbukti dari hasil wawancara dengan seorang guru kelas V mata pelajaran Ilmu Pengetahuan Sosial di SD No. 2 Petandakan yang menyatakan bahwa hasil belajar pembelajaran Ilmu Pengetahuan Sosial pada siswa kelas V di Sekolah Dasar No. 2 Petandakan masih rendah. Hal tersebut dikarenakan siswa kurang

\footnotetext{
* Corresponding author.

E-mail Addresses imadecitra.wibawa@undiksha.ac.id (I Made Citra Wibawa), sukmayasa@yahoo.com (I Made Hendra Sukmayasa),
} 
bersemangat dalam mengikuti pembelajaran. Dampak dari kurangnya semangat siswa dalam mengikuti pembelajaran tercermin pada hasil belajar pelajaran Ilmu Pengetahuan Sosial yang diperoleh siswa rataratanya hanya 56,21. Hal ini juga diperkuat dengan hasil tes awal yang hanya mendapatkan angka ratarata 57.14. Kedua hasil belajar tersebut belum memenuhi kriteria ketuntasan minimal yang ditetapkan oleh sekolah yakni 60,00.

Hal ini menunjukan bahwa terjadi kesenjangan antara yang diharapkan sekolah yakni siswanya tuntas belajar jika mendapatkan nilai minimal 60,00 namun kenyataan hasil yang dicapai siswanya rataratanya masih di bawah 60,00 yakni 56,21 sehingga hal tersebut menjadi masalah yang perlu dicari solusinya. Maka dari itu penelitian ini dilaksanakan untuk memecahkan masalah tersebut.Untuk membatasi ruang lingkup masalah yang dibahas dalam penelitian ini, maka perlu adanya pembatasan masalah. Penelitian ini hanya dilakukan pada mata pelajaran Ilmu Pengetahuan Sosial untuk konsep/sub konsep Perjuangan Melawan Penjajahan di kelas V, semester II pada SD No. 2 Petandakan tahun pelajaran 2010/2011 dengan judul Penerapan Model Pembelajaran Kooperatif Tipe Jigsaw untuk Meningkatkan Hasil Belajar Ilmu Pengetahuan Sosial pada Siswa Kelas V Semester II Sekolah Dasar NO. 2 Petandakan Kecamatan Buleleng Kabupaten Buleleng Tahun Pelajaran 2010/2011.

\section{Metode}

Dalam penelitian ini yang menjadi subjek penelitian adalah siswa SD No. 2 Petandakan kelas V semester II Kecamatan Buleleng, Kabupaten Buleleng tahun pelajaran 2010/2011 sebanyak 14 orang, yakni 5 orang siswa laki-laki dan 9 orang siswa perempuan.Terdapat satu variabel yang menjadi fokus perhatian dalam penelitian ini yaitu hasil belajar mata pelajaran Ilmu Pengetahuan Sosial setelah penerapan Model Pembelajaran Koperatif tipe Jigsaw.

Hasil belajar Ilmu Pengetahuan Sosial adalah suatu perubahan yang terjadi pada kemampuan diri siswa dalam aspek kognitif, yang ditunjukkan dengan skor yang dicapai siswa setelah penerapan Model Pembelajaran Koperatif tipe Jigsaw. Dalam proses belajar Ilmu Pengetahuan Sosial hasil belajar yang dicapai siswa mencakup tiga ranah yaitu ranah kognitif, afektif dan psikomotorik. Namun dalam penelitian ini, hasil belajar Ilmu Pengetahuan Sosial yang dimaksud dibatasi hanya pada ranah kognitif saja. Hasil belajar Ilmu Pengetahuan Sosial diukur dengan metode tes dan instrumen berupa tes objektif pilihan ganda dan tes isian singkat. Dengan cara demikian, maka data tentang hasil belajar Ilmu Pengetahuan Sosial yang diperoleh berupa skor.

Dalam penelitian tindakan kelas (PTK) ini mengacu pada teori yang dikemukakan Stephen Kemmis dan Robin McTaggart (dalam Agung, 2005). Dalam model PTK ini ada empat tahapan pada satu siklus penelitian. Keempat tahapan trsebut terdiri dari: perencanaan, tindakan, observasi/evaluasi dan refleksi. Pelaksanaan penelitian di lakukan dalam tiga siklus, dan ketiga siklus tersebut dapat digambarkan dalam model seperti gambar sebagai berikut.

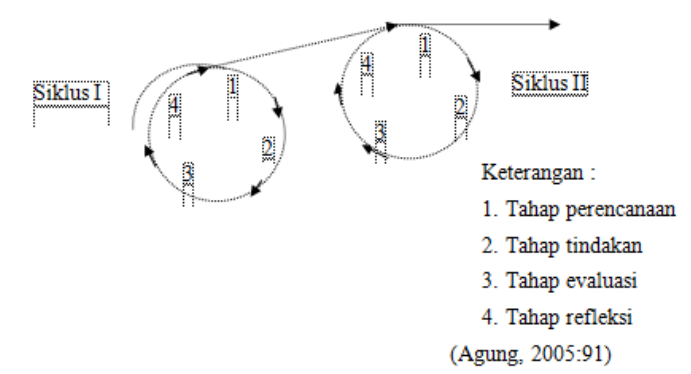

Gambar 1. Model Siklus PenelitianTindakan Kelas

\section{Hasil Dan Pembahasan}

Hasil Belajar IPS Siswa Dengan Model Pembelajaran Kooperatif Tipe Jigsaw Selama penerapan model pembelajaran kooperatif tipe jigsaw, peneliti melakukan penilaian proses pembelajaran dan hasil belajar siswa. Untuk proses pembelajaran, peneliti menggunakan lembar observasi untuk menilai kegiatan siswa dan menilai kegiatan peneliti yang dibantu oleh guru mata pelajaran. Berikut ini lembar observasi kegiatan peneliti dan lembar observasi kegiatan siswa yang digunakan peneliti selama menilai proses pembelajaran dikelas. 
Tabel 2. Lembar Observasi Kegiatan Peneliti

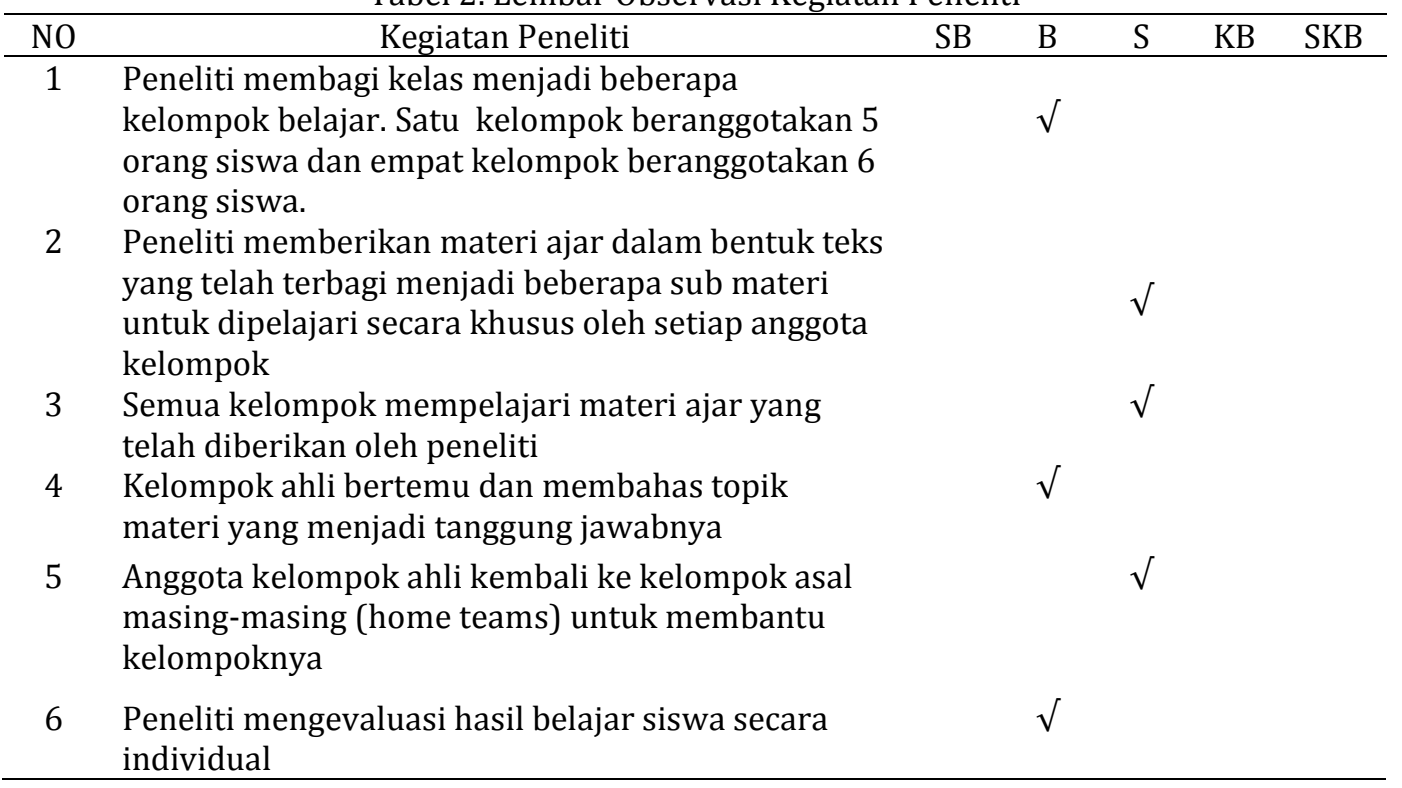

Tabel 3. Lembar Observasi Kegiatan Siswa

\begin{tabular}{|c|c|c|c|c|c|c|}
\hline NO & Kegiatan Siswa & SB & $\mathrm{B}$ & $\mathrm{S}$ & KB & SKB \\
\hline 1 & $\begin{array}{l}\text { Siswa membentuk kelompok belajar sesuai dengan } \\
\text { anggota yang ditentukan }\end{array}$ & & & $\sqrt{ }$ & & \\
\hline 2 & $\begin{array}{l}\text { Siswa mendapatkan materi yang berbeda untuk } \\
\text { untuk dipelajari selanjutnya }\end{array}$ & & $\sqrt{ }$ & & & \\
\hline 3 & $\begin{array}{l}\text { Siswa mempelajari dan memahami materi yang } \\
\text { sudah didapat }\end{array}$ & & & $\sqrt{ }$ & & \\
\hline 4 & $\begin{array}{l}\text { Siswa yang mendapatkan materi yang sama } \\
\text { berkumpul dalam kelompok ahli dan membahas } \\
\text { topik sesuai dengan tanggung jawabnya }\end{array}$ & & & $\sqrt{ }$ & & \\
\hline 5 & $\begin{array}{l}\text { Siswa kembali ke kelompok asal (home teams) dan } \\
\text { mulai menjelaskan kepada kelompoknya mengenai } \\
\text { materi yang dibahas dalam kelompok ahli }\end{array}$ & & & $\sqrt{ }$ & & \\
\hline 6 & Siswa mengikuti evaluasi secara individual & & $\sqrt{ }$ & & & \\
\hline
\end{tabular}

Dari tes yang dilakukan, peneliti mendapatkan hasil belajar siswa pada siklus I mata pelajaran IPS dengan penerapan model pembelajaran kooperatif tipe jigsaw pada materi pokok persiapan kemerdekaan Indonesia serta perumusan dasar negara pada siklus pertama dapat dilihat pada tabel 4 .

Tabel 4. Hasil Belajar Siswa dan Ketuntasan Belajar Siklus I

\begin{tabular}{cccc}
\hline No & Subjek & Nilai & Ket \\
\hline 1 & A & 80 & Tuntas \\
2 & B & 40 & Tidak Tuntas \\
3 & C & 70 & Tuntas \\
4 & D & 60 & Tuntas \\
5 & E & 50 & Tidak Tuntas \\
6 & F & 80 & Tuntas \\
7 & G & 90 & Tuntas \\
8 & H & 80 & Tuntas \\
9 & I & 70 & Tuntas \\
10 & J & 80 & Tuntas \\
11 & K & 50 & Tidak Tuntas \\
12 & L & 60 & Tuntas \\
13 & M & 80 & Tuntas \\
14 & N & 50 & Tidak Tuntas \\
\hline
\end{tabular}




\section{Deskripsi Data Hasil Belajar Penelitian}

Dalam analisis Statistik Deskriptif ini data secara berturut-turut disajikan ke dalam: a) table distribusi frekuensi, b) menghitung mean (M), median (Me), dan modus (Mo), c) menggambar grafik polygon dan menentukan letak $\mathrm{M}$, Me, dan Mo pada grafik teresbut, d) membandingkan rata-rata $\mathrm{M}$ tersebut dengan lima criteria model skala PAP skala-5 sehingga diperoleh simpulan: sangat tinggi/ tinggi/ sedang/ rendah/ sangat rendah.a. Menyajikan Data ke dalam Tabel Distribusi Frekuensi. Data hasil penelitian siklus I ini disajikan pada tabel 5 distribusi frekuensi sebagai berikut.

Tabel 5. Data Hasil Belajar Mata Pelajaran Ilmu Pengetahuan Sosial Pada Siklus I

\begin{tabular}{cccccc}
\hline Kelas interval & $\begin{array}{c}\text { Titik tengah } \\
(\mathrm{X})\end{array}$ & $\begin{array}{c}\text { Frekuensi } \\
(\mathrm{f})\end{array}$ & $\begin{array}{c}\text { Frekuensi } \\
\text { komulatif }(\mathrm{fk})\end{array}$ & $\mathrm{x}^{\prime}$ & $\mathrm{fx}^{\prime}$ \\
\hline $90-81$ & 85,5 & 1 & 14 & +2 & 2 \\
$80-71$ & 75,5 & 5 & 13 & +1 & 5 \\
$70-61$ & 65,5 & 2 & 8 & 0 & 0 \\
$60-51$ & 55,5 & 2 & 6 & -1 & -2 \\
$50-41$ & 45,5 & 3 & 4 & -2 & -6 \\
$40-31$ & 35,5 & 1 & 1 & -3 & -3 \\
\hline Total & - & 14 & - & - & -4 \\
\hline
\end{tabular}

\section{Analisis Statistik Kuantitatif}

Berdasarkan hasil analisis data di atas maka tingkatan hasil belajar mata pelajaran Ilmu Pengetahuan Sosial berdasarkan PAP skala lima berada pada katagori Sedang.Jumlah siswa dan persentase siswa yang mencapai ketuntasan belajar dan siswa yang tidak mencapai ketuntasan belajar dapat dilihat pada tabel 6.

Tabel 6. Persentase Ketuntasan Belajar Siswa Siklus I

\begin{tabular}{cccc}
\hline Siklus & Rata-rata & $\begin{array}{c}\text { Jumlah Siswa yang } \\
\text { mencapai KKM }\end{array}$ & $\begin{array}{c}\text { Jumlah siswa yang tidak } \\
\text { mencapai KKM }\end{array}$ \\
I & 62,64 & $10(71,43 \%)$ & $4(28,57 \%)$ \\
\hline
\end{tabular}

Tabel 6 menunjukkan pada siklus pertama, siswa yang mengalami ketuntasan belajar sebanyak 10 orang dan siswa yang belum mencapai ketuntasan belajar sebanyak 4 orang.Persentase ketuntasan siklus I adalah 71, 43\%. Hal tersebut menunjukan bahwa ketetapan ketuntasan belajar $80 \%$ belum tercapai, maka dari itu akan dilaksanakan siklus II guna memperbaiki permasalahan atau kendala yang terjadi pada siklus I sehingga ketuntasan belajar siswa diharapkan dapat meningkat.Setelah kegiatan siklus pertama berakhir, maka peneliti melakukan refleksi untuk mengetahui kegiatan yang sudah dilaksanakan seperti kendala-kendala yang dihadapi dan merancang kegiatan selanjutnya agar kendalakendala tersebut dapat diatasi.Hasil observasi pada siklus I menunjukkan bahwa dalam penerapan model pembelajaran kooperatif tipe jigsaw terdapat beberapa kendala atau permasalahan yang harus diperbaiki. Adapun kendala atau permasalahan tersebut adalah sebagai berikut: 1). siswa merasa bingung tentang cara belajar kelompok dalam model pembelajaran kooperatif tipe jigsaw. 2). siswa sulit untuk menyampaikan informasi kepada teman kelompoknya dan sulit menerima informasi dari teman dalam kelompoknya. 3). siswa sulit membuat kesimpulan dari apa yang telah mereka pelajari.

Untuk menanggulangi permasalahan yang timbul dalam proses pembelajaran tersebut maka peneliti dibantu dengan guru mata pelajaran memberikan informasi yang lebih detail dan mengarahkan siswa sesuai dengan prosedur pembelajaran kooperatif tipe jigsaw. Pada saat penyampaian informasi dari anggota ahli kepada kelompok asal dan pembuatan kesimpulan dari apa yang mereka pelajari, peneliti dan guru akan mengawasi dan menyimak penjelasan yang diberikan agar dapat meluruskan hal-hal yang dianggap tidak sesuai dengan materi ahli yang dibahas.Dari permasalahan yang ditemui dalam siklus pertama, ada beberapa kelebihan yang diperoleh pada proses pembelajaran IPS dengan menggunakan model pembelajaran kooperatif tipe jigsaw yakni: 1) siswa lebih mudah untuk mempelajari IPS karena materinya sudah dipilah-pilah sehingga siswa tidak merasa jenuh untuk mempelajarinya, 2) siswa lebih aktif dalam mengikuti pembelajaran karena dalam pembelajaran ini berpusat kepada siswa dan guru hanya sebagai fasilitator saja.

Pada siklus pertama diperoleh rata-rata hasil belajar siswa sebesar 62,64. Jumlah siswa yang mencapai KKM 60 sebanyak 10 orang dan siswa yang tidak mencapai KKM 60 sebanyak 4 orang. Dengan demikian ketuntasan belajar siswa pada siklus pertama 71,43\%. Berdasarkan data nilai tersebut ketuntasan belajar belum tercapai sesuai dengan kriteria hasil belajar siswa yaitu $80 \%$ siswa mencapai 
KKM 60. Maka dari itu peneliti akan mengadakan siklus II dengan memperhatikan kendala atau permasalahan yang terjadi pada siklus I, sehingga pada siklus II permasalahan tersebut dapat diatasi

Penerapan model pembelajaran kooperatif tipe jigsaw pada siklus kedua, peneliti tetap melakukan penilaian proses pembelajaran dan hasil belajar siswa. Untuk proses pembelajaran, peneliti menggunakan lembar observasi untuk menilai kegiatan siswa dan menilai kegiatan peneliti yang dibantu oleh guru mata pelajaran. Berikut ini lembar observasi kegiatan peneliti dan lembar observasi kegiatan siswa yang digunakan peneliti selama menilai proses pembelajaran dikelas.

Tabel 7. Lembar Observasi Kegiatan Peneliti

\begin{tabular}{|c|c|c|c|c|c|c|}
\hline NO & Kegiatan Peneliti & SB & B & $\mathrm{S}$ & KB & SKB \\
\hline 1 & $\begin{array}{l}\text { Peneliti membagi kelas menjadi beberapa kelompok } \\
\text { belajar. Satu kelompok beranggotakan } 5 \text { orang } \\
\text { siswa dan empat kelompok beranggotakan } 6 \text { orang } \\
\text { siswa. }\end{array}$ & & $\sqrt{ }$ & & & \\
\hline 2 & $\begin{array}{l}\text { Peneliti memberikan materi ajar dalam bentuk teks } \\
\text { yang telah terbagi menjadi beberapa sub materi } \\
\text { untuk dipelajari secara khusus oleh setiap anggota } \\
\text { kelompok }\end{array}$ & & $\sqrt{ }$ & & & \\
\hline 3 & $\begin{array}{l}\text { Semua kelompok mempelajari materi ajar yang } \\
\text { telah diberikan oleh peneliti }\end{array}$ & & $\sqrt{ }$ & & & \\
\hline 4 & $\begin{array}{l}\text { Kelompok ahli bertemu dan membahas topik materi } \\
\text { yang menjadi tanggung jawabnya }\end{array}$ & & $\sqrt{ }$ & & & \\
\hline 5 & $\begin{array}{l}\text { Anggota kelompok ahli kembali ke kelompok asal } \\
\text { masing-masing (home teams) untuk membantu } \\
\text { kelompoknya }\end{array}$ & & & $\sqrt{ }$ & & \\
\hline 6 & $\begin{array}{l}\text { Peneliti mengevaluasi hasil belajar siswa secara } \\
\text { individual }\end{array}$ & & $\sqrt{ }$ & & & \\
\hline \multicolumn{7}{|c|}{ Tabel 8. Lembar Observasi Kegiatan Siswa } \\
\hline NO & Kegiatan Siswa & SB & $\mathrm{B}$ & $\mathrm{S}$ & KB & SKB \\
\hline 1 & $\begin{array}{l}\text { Siswa membentuk kelompok belajar sesuai dengan } \\
\text { anggota yang ditentukan }\end{array}$ & & $\sqrt{ }$ & & & \\
\hline 2 & $\begin{array}{l}\text { Siswa mendapatkan materi yang berbeda untuk } \\
\text { untuk dipelajari selanjutnya }\end{array}$ & & $\sqrt{ }$ & & & \\
\hline 3 & $\begin{array}{l}\text { Siswa mempelajari dan memahami materi yang } \\
\text { sudah didapat }\end{array}$ & & $\sqrt{ }$ & & & \\
\hline 4 & $\begin{array}{l}\text { Siswa yang mendapatkan materi yang sama } \\
\text { berkumpul dalam kelompok ahli dan membahas } \\
\text { topik sesuai dengan tanggung jawabnya }\end{array}$ & & $\sqrt{ }$ & & & \\
\hline 5 & $\begin{array}{l}\text { Siswa kembali ke kelompok asal (home teams) dan } \\
\text { mulai menjelaskan kepada kelompoknya mengenai } \\
\text { materi yang dibahas dalam kelompok ahli }\end{array}$ & & & $\sqrt{ }$ & & \\
\hline 6 & Siswa mengikuti evaluasi secara individual & & $\sqrt{ }$ & & & \\
\hline
\end{tabular}

Dari tes yang dilakukan, peneliti mendapatkan hasil belajar siswa pada siklus II mata pelajaran IPS dengan penerapan model pembelajaran kooperatif tipe jigsaw pada materi peranan tokoh pejuang dalam memproklamasikan kemerdekaan Indonesiapada siklus II dapat dilihat pada tabel 9.

Tabel 9. Hasil Belajar Siswa dan Ketuntasan Belajar Siklus II

\begin{tabular}{cccc}
\hline No & Subjek & Nilai & Ket \\
\hline 1 & A & 90 & Tuntas \\
2 & B & 50 & Tidak Tuntas \\
3 & C & 90 & Tuntas \\
4 & D & 80 & Tuntas \\
5 & E & 60 & Tuntas \\
6 & F & 80 & Tuntas \\
7 & G & 80 & Tuntas
\end{tabular}




\begin{tabular}{cccc}
\hline No & Subjek & Nilai & Ket \\
\hline 8 & H & 80 & Tuntas \\
9 & I & 70 & Tuntas \\
10 & J & 90 & Tuntas \\
11 & K & 70 & Tuntas \\
12 & L & 50 & Tidak Tuntas \\
13 & M & 80 & Tuntas \\
\hline 14 & N & 50 & Tidak Tuntas \\
\hline
\end{tabular}

Dalam analisis Statistik Deskriptif ini data secara berturut-turut disajikan ke dalam: a) table distribusi frekuensi, b) menghitung mean (M), median (Me), dan modus (Mo), c) menggambar grafik polygon dan menentukan letak $\mathrm{M}, \mathrm{Me}$, dan Mo pada grafik teresbut, d) membandingkan rata-rata $\mathrm{M}$ tersebut dengan lima criteria model skala PAP skala-5 sehingga diperoleh simpulan: sangat tinggi/ tinggi/ sedang/ rendah/ sangat rendah. a. Menyajikan Data ke dalam Tabel Distribusi Frekuensi. Data hasil penelitian siklus II ini disajikan pada tabel 10 distribusi frekuensi sebagai berikut.

Tabel 10.Data Hasil Belajar Mata Pelajaran Ilmu Pengetahuan Sosial Pada Siklus II

\begin{tabular}{cccccc}
\hline $\begin{array}{c}\text { Kelas } \\
\text { interval }\end{array}$ & $\begin{array}{c}\text { Titik tengah } \\
(\mathrm{X})\end{array}$ & $\begin{array}{c}\text { Frekuensi } \\
(\mathrm{f})\end{array}$ & $\begin{array}{c}\text { Frekuensi } \\
\text { komulatif }(\mathrm{fk})\end{array}$ & $\mathrm{x}^{\prime}$ & $\mathrm{fx}^{\prime}$ \\
\hline $90-81$ & 85,5 & 3 & 14 & +1 & 3 \\
$80-71$ & 75,5 & 5 & 11 & 0 & 0 \\
$70-61$ & 65,5 & 2 & 6 & -1 & -2 \\
$60-51$ & 55,5 & 1 & 4 & -2 & -4 \\
$50-41$ & 45,5 & 3 & 3 & -3 & -9 \\
\hline Total & - & 14 & - & - & -12 \\
\hline
\end{tabular}

Berdasarkan hasil analisis data di atas maka tingkatan hasil belajar mata pelajaran Ilmu Pengetahuan Sosial berdasarkan PAP skala lima berada pada katagori Sedang.

Jumlah siswa dan persentase siswa yang mencapai ketuntasan belajar dan siswa yang tidak mencapai ketuntasan belajar dapat dilihat pada tabel 11 .

Tabel 11. Persentase Ketuntasan Belajar Siswa Siklus II

\begin{tabular}{cccc}
\hline Siklus & Rata-rata & $\begin{array}{c}\text { Jumlah Siswa yang } \\
\text { mencapai KKM }\end{array}$ & $\begin{array}{c}\text { Jumlah siswa yang tidak } \\
\text { mencapai KKM }\end{array}$ \\
\hline II & 66,93 & $11(78,57 \%)$ & $3(21,43 \%)$ \\
\hline
\end{tabular}

Tabel 11 menunjukkan pada siklus II, siswa yang mengalami ketuntasan belajar sebanyak 11 orang dan siswa yang belum mencapai ketuntasan belajar sebanyak 3 orang. Persentase ketuntasan siklus II adalah 78,57\%. Hal tersebut menunjukan bahwa ketetapan ketuntasan belajar $80 \%$ belum tercapai, maka dari itu akan dilaksanakan siklus III guna memperbaiki permasalahan atau kendala yang terjadi pada siklus II sehingga ketuntasan belajar siswa diharapkan dapat meningkat.

Pada saat proses pembelajaran pada siklus kedua sudah semakin baik. Hal ini terbukti sebagai berikut: a). siswa sudah dapat mengikuti proses pembelajaran sesuai dengan prosedur model pembelajaran kooperatif tipe jigsaw, b). siswa sudah dapat membuat kesimpulan dari apa yang telah mereka pelajari. Ketuntasan belajar yang diperoleh siswa mengalami peningkatan dari siklus pertama ke siklus kedua sebesar 7,14\% dan rata-rata hasil belajar siswapun meningkat dari 62,64 menjadi 66,93. Hal tersebut dapat dilihat pada tabel di bawah ini.

Tabel 12.Persentase Ketuntasan Belajar Siswa Siklus I dan II

\begin{tabular}{cccc}
\hline Siklus & Rata-rata & $\begin{array}{c}\text { Jumlah Siswa yang } \\
\text { mencapai KKM }\end{array}$ & $\begin{array}{c}\text { Jumlah siswa yang tidak } \\
\text { mencapai KKM }\end{array}$ \\
\hline I & 62,64 & $10(71,43 \%)$ & $4(28,57 \%)$ \\
II & 66,93 & $11(78,57 \%)$ & $3(21,43 \%)$ \\
\hline
\end{tabular}

Berdasarkan hasil observasi pada siklus II menunjukkan bahwa dalam penerapan model pembelajaran kooperatif tipe jigsaw terdapat satu kendala atau permasalahan yang harus diperbaiki. Adapun kendala atau permasalahan tersebut adalah siswa masih sulit untuk menyampaikan informasi kepada teman kelompoknya dan sulit menerima informasi dari teman dalam kelompoknya.Untuk 
mengatasi hal tersebut maka peneliti dibantu dengan guru mata pelajaran lebih fokus mengawasi dan menyimak penjelasan yang diberikan agar dapat meluruskan hal-hal yang dianggap tidak sesuai dengan materi ahli yang dibahas.

Pada siklus kedua diperoleh rata-rata hasil belajar siswa sebesar 66,93.Jumlah siswa yang mencapai KKM 60 sebanyak 11 orang dan siswa yang tidak mencapai KKM 60 sebanyak 3 orang.Dengan demikian ketuntasan belajar siswa pada siklus kedua 78, 57\%.Berdasarkan data nilai tersebut ketuntasan belajar belum tercapai sesuai dengan kriteria hasil belajar siswa yaitu 80\% siswa mencapai KKM 60. Maka dari itu peneliti akan mengadakan siklus III dengan memperhatikan kendala atau permasalahan yang terjadi pada siklus II, sehingga pada siklus III permasalahan tersebut dapat diatasi. Penerapan model pembelajaran kooperatif tipe jigsaw pada siklus III, peneliti tetap melakukan penilaian proses pembelajaran dan hasil belajar siswa. Untuk proses pembelajaran, peneliti menggunakan lembar observasi untuk menilai kegiatan siswa dan menilai kegiatan peneliti yang dibantu oleh guru mata pelajaran. Berikut ini lembar observasi kegiatan peneliti dan lembar observasi kegiatan siswa yang digunakan peneliti selama menilai proses pembelajaran dikelas.

Tabel 13. Lembar Observasi Kegiatan Peneliti

\begin{tabular}{|c|c|c|c|c|c|c|}
\hline NO & Kegiatan Peneliti & SB & B & $\mathrm{S}$ & KB & SKB \\
\hline 1 & $\begin{array}{l}\text { Peneliti membagi kelas menjadi beberapa } \\
\text { kelompok belajar. Satu kelompok beranggotakan } 5 \\
\text { orang siswa dan empat kelompok beranggotakan } 6 \\
\text { orang siswa. }\end{array}$ & & $\sqrt{ }$ & & & \\
\hline 2 & $\begin{array}{l}\text { Peneliti memberikan materi ajar dalam bentuk teks } \\
\text { yang telah terbagi menjadi beberapa sub materi } \\
\text { untuk dipelajari secara khusus oleh setiap anggota } \\
\text { kelompok }\end{array}$ & & $\sqrt{ }$ & & & \\
\hline 3 & $\begin{array}{l}\text { Semua kelompok mempelajari materi ajar yang } \\
\text { telah diberikan oleh peneliti }\end{array}$ & & $\sqrt{ }$ & & & \\
\hline 4 & $\begin{array}{l}\text { Kelompok ahli bertemu dan membahas topik } \\
\text { materi yang menjadi tanggung jawabnya }\end{array}$ & & $\sqrt{ }$ & & & \\
\hline 5 & $\begin{array}{l}\text { Anggota kelompok ahli kembali ke kelompok asal } \\
\text { masing-masing (home teams) untuk membantu } \\
\text { kelompoknya }\end{array}$ & & $\sqrt{ }$ & & & \\
\hline 6 & $\begin{array}{l}\text { Peneliti mengevaluasi hasil belajar siswa secara } \\
\text { individual }\end{array}$ & & $\sqrt{ }$ & & & \\
\hline
\end{tabular}

Dari tes yang dilakukan, peneliti mendapatkan hasil belajar siswa pada siklus III mata pelajaran IPS dengan penerapan model pembelajaran kooperatif tipe jigsaw pada materi pokok Peristiwa Menjelang Proklamasi Kemerdekaan pada siklus III dapat dilihat pada tabel 14.

Tabel 14. Hasil Belajar Siswa dan Ketuntasan Belajar Siklus III

\begin{tabular}{cccc}
\hline No & Subjek & Nilai & Ket \\
\hline 1 & A & 100 & Tuntas \\
2 & B & 70 & Tuntas \\
3 & C & 80 & Tuntas \\
4 & D & 90 & Tuntas \\
5 & E & 60 & Tuntas \\
6 & F & 70 & Tuntas \\
7 & G & 80 & Tuntas \\
8 & H & 80 & Tuntas \\
9 & I & 80 & Tuntas \\
10 & J & 90 & Tuntas \\
11 & K & 70 & Tuntas \\
12 & L & 80 & Tuntas \\
13 & M & 80 & Tuntas \\
14 & N & 70 & Tuntas \\
\hline
\end{tabular}




\section{Deskripsi Data Hasil Belajar Penelitian}

Dalam analisis Statistik Deskriptif ini data secara berturut-turut disajikan ke dalam: a) table distribusi frekuensi, b) menghitung mean (M), median (Me), dan modus (Mo), c) menggambar grafik polygon dan menentukan letak $\mathrm{M}$, Me, dan Mo pada grafik teresbut, d) membandingkan rata-rata $\mathrm{M}$ tersebut dengan lima criteria model skala PAP skala-5 sehingga diperoleh simpulan: sangat tinggi/ tinggi/ sedang/ rendah/ sangat rendah.a. Menyajikan Data ke dalam Tabel Distribusi Frekuensi. Data hasil penelitian siklus III ini disajikan pada table distribusi frekuensi sebagai berikut.

Tabel 15. Data Hasil Belajar Mata Pelajaran Ilmu Pengetahuan Sosial Pada Siklus III

\begin{tabular}{cccccc}
\hline Kelas interval & $\begin{array}{c}\text { Titik tengah } \\
(\mathrm{X})\end{array}$ & $\begin{array}{c}\text { Frekuensi } \\
(\mathrm{f})\end{array}$ & $\begin{array}{c}\text { Frekuensi } \\
\text { komulatif }(\mathrm{fk})\end{array}$ & $\mathrm{x}^{\prime}$ & $\mathrm{fx}^{\prime}$ \\
\hline $100-91$ & 95,5 & 1 & 14 & +2 & 2 \\
$90-81$ & 85,5 & 2 & 13 & +1 & 2 \\
$80-71$ & 75,5 & 6 & 11 & 0 & 0 \\
$70-61$ & 65,5 & 4 & 5 & -1 & -4 \\
$60-51$ & 55,5 & 1 & 4 & -2 & -2 \\
\hline Total & - & 14 & - & - & -2 \\
\hline
\end{tabular}

Berdasarkan hasil analisis data di atas maka tingkatan hasil belajar mata pelajaran Ilmu Pengetahuan Sosial berdasarkan PAP skala lima berada pada katagori Sedang. Jumlah siswa dan persentase siswa yang mencapai ketuntasan belajar dan siswa yang tidak mencapai ketuntasan belajar dapat dilihat pada tabel 16

Tabel 16.Persentase Ketuntasan Belajar Siswa Siklus III

\begin{tabular}{|c|c|c|c|}
\hline Siklus & Rata-rata & $\begin{array}{c}\text { Jumlah Siswa yang } \\
\text { mencapai KKM }\end{array}$ & $\begin{array}{c}\text { Jumlah siswa yang tidak } \\
\text { mencapai KKM }\end{array}$ \\
\hline III & 74,07 & $14(100 \%)$ & $0(0 \%)$ \\
\hline
\end{tabular}

Pada saat proses pembelajaran pada siklus III sudah semakin baik. Hal ini terbukti dari siswa sudah mampu untuk menyampaikan informasi kepada teman kelompoknya dan menerima informasi dari teman dalam kelompoknya dengan baik.Ketuntasan belajar yang diperoleh siswa mengalami peningkatan dari siklus II ke siklus III sebesar $21,43 \%$ dan rata-rata hasil belajar siswapun meningkat dari 66,93 menjadi 74,07. Hal tersebut dapat dilihat pada tabel 17 di bawah ini.

Tabel 17 Persentase Ketuntasan Belajar Siswa Siklus I, II, dan III

\begin{tabular}{cccc}
\hline Siklus & Rata-rata & $\begin{array}{c}\text { Jumlah Siswa yang } \\
\text { mencapai KKM }\end{array}$ & $\begin{array}{c}\text { Jumlah siswa yang tidak } \\
\text { mencapai KKM }\end{array}$ \\
\hline I & 62,64 & $10(71,43 \%)$ & $4(28,57 \%)$ \\
II & 66,93 & $11(78,57 \%)$ & $3(21,43 \%)$ \\
\hline III & 74,07 & $14(100 \%)$ & $0(0 \%)$ \\
\hline
\end{tabular}

Berdasarkan hasil refleksi dari siklus III di atas maka ketetapan ketuntasan belajar $80 \%$ sudah tercapai, maka dari itu penelitian ini dapat dinyatakan telah berhasil dan siklus pun tidak dilanjutkan kembali. Model Pembelajaran kooperatif tipe jigsaw menekankan pada kemampuan setiap siswa untuk menguasai satu materi dan bertanggung jawab untuk menyampaikan informasi dan pengetahuan yang dimilikinya kepada teman dalam kelompoknya. Dalam penerapan model pembelajaran kooperatif tipe jigsaw, guru melakukan observasi terhadap kegiatan siswa dan kegiatan peneliti dengan menggunakan lembar observasi. Hal tersebut bertujuan agar peneliti dapat mengetahui kelemahan dan kekurangan yang terjadi selama proses pembelajaran IPS berlangsung baik dari pihak peneliti ataupun dari pihak siswa. Strategi pembelajaran kooperatif tipe jigsaw pertama kali diterapkan di kelas V SD No. 2 Petandakan pada saat pembelajaran IPS.Hal tersebut terlihat pada siklus pertama siswa merasa bingung mencari kelompok asal dan kelompok ahli.dalam proses pembelajaran di kelas. Penyampaian informasi dari masing-masing anggota ahli kurang efektif karena siswa belum memahami dan menguasai materi yang menjadi tanggung jawabnya.Hal ini membuat informasi tidak tersampaikan secara utuh dan merata di setiap siswa sehingga mempengaruhi hasil belajar siswa. Dari data yang diperoleh dengan memberikan tes individual pada akhir pembelajaran, sebanyak 4 orang siswa $(28,57 \%)$ belum mencapai KKM dan sebanyak 10 orang siswa $(71,43 \%)$ sudah mencapai KKM dengan rata-rata kelas 62,64.

Hasil observasi dan hasil belajar yang diperoleh pada siklus pertama belum memenuhi kriteria keberhasilan yang ingin dicapai oleh peneliti.Untuk itu peneliti melaksanakan siklus kedua sebagai upaya 
untuk meningkatkan hasil belajar siswa agar mencapai KKM yang ditetapkan sekolah yaitu 60. Sebelum melakukan proses pembelajaran IPS dengan menggunakan model pembelajaran kooperatif tipe jigsaw pada siklus kedua, peneliti bersama guru mata pelajaran melakukan refleksi terhadap kegiatan pada siklus pertama. Dari refleksi tersebut ditemukan kelemahan dalam penerapan model pembelajaran kooperatif tipe jigsaw antara lain: a). siswa merasa bingung tentang cara belajar kelompok dalam model pembelajaran kooperatif tipe jigsaw, b). siswa sulit untuk menyampaikan informasi kepada teman kelompoknya dan sulit menerima informasi dari teman dalam kelompoknya, c). siswa sulit membuat kesimpulan dari apa yang telah mereka pelajari.

Hasil refleksi tersebut digunakan sebagai dasar untuk memperbaiki kesalahan-kesalahan yang terjadi pada siklus pertama agar tidak terulang kembali pada siklus kedua.Pada siklus kedua, peneliti berkolaborasi kembali dengan guru mata pelajaran merancang pembelajaran menggunakan model pembelajaran kooperatif tipe jigsaw agar dapat meningkatkan hasil belajar siswa sesuai dengan KKM yang ditetapkan oleh sekolah.Perencanaan, pelaksanaan, sampai evaluasi siklus kedua hampir sama dengan siklus pertama. Pembelajaran IPS yang berlangsung pada siklus kedua melakukan penilaian terhadap hasil belajar siswa melalui tes akhir secara individual. Proses pembelajaran siswa dinilai melalui lembar observasi kegiatan yang dibantu oleh guru mata pelajaran. Berdasarkan hasil observasi kegiatan siswa selama proses pembelajaran pada siklus kedua, siswa sudah mengalami peningkatan dalam mengikuti langkah-langkah pembelajaran kooperatif tipe jigsaw antara lain. A). siswa sudah dapat mengikuti proses pembelajaran sesuai dengan prosedur model pembelajaran kooperatif tipe jigsaw, b). siswa sudah dapat membuat kesimpulan dari apa yang telah mereka pelajari.

Namun dalam penyampaian informasi dari masing-masing anggota ahli masih kurang efektif karena siswa belum memahami dan menguasai materi yang menjadi tanggung jawabnya.Hal ini membuat informasi tidak tersampaikan secara utuh dan merata di setiap siswa sehingga mempengaruhi hasil belajar siswa. Dari data yang diperoleh dengan memberikan tes individual pada akhir pembelajaran, sebanyak 3 orang siswa $(21,43 \%)$ belum mencapai KKM dan sebanyak 11 orang siswa $(78,57 \%)$ sudah mencapai KKM dengan rata-rata kelas 66,93 . Hasil observasi dan hasil belajar yang diperoleh pada siklus kedua belum memenuhi kriteria keberhasilan yang ingin dicapai oleh peneliti.Untuk itu peneliti melaksanakan siklus ketiga sebagai upaya untuk meningkatkan hasil belajar siswa agar mencapai KKM yang ditetapkan sekolah yaitu 60. Sebelum melakukan proses pembelajaran IPS dengan menggunakan model pembelajaran kooperatif tipe jigsaw pada siklus kedua, peneliti bersama guru mata pelajaran melakukan refleksi terhadap kegiatan pada siklus kedua. Dari refleksi tersebut ditemukan kelemahan atau kendala dalam penerapan model pembelajaran kooperatif tipe jigsaw yakni siswa masih sulit untuk menyampaikan informasi kepada teman kelompoknya dan sulit menerima informasi dari teman dalam kelompoknya.Hasil refleksi tersebut digunakan sebagai dasar untuk memperbaiki kesalahan-kesalahan yang terjadi pada siklus kedua agar tidak terulang kembali pada siklus ketiga.Pada siklus ketiga, peneliti berkolaborasi kembali dengan guru mata pelajaran merancang pembelajaran menggunakan model pembelajaran kooperatif tipe jigsaw agar dapat meningkatkan hasil belajar siswa sesuai dengan KKM yang ditetapkan oleh sekolah.

Perencanaan, pelaksanaan, sampai evaluasi siklus ketiga hampir sama dengan siklus pertama. Namun peneliti dan guru mata pelajaran akan lebih fokus mengawasi dan menyimak penjelasan yang diberikan siswa kepada temannya agar dapat meluruskan hal-hal yang dianggap tidak sesuai dengan materi ahli yang dibahas Pembelajaran IPS yang berlangsung pada siklus ketiga. Untuk melakukan penilaian terhadap hasil belajar siswa dilaksanakan melalui tes akhir secara individual. Proses pembelajaran siswa dinilai melalui lembar observasi kegiatan yang dibantu oleh guru mata pelajaran. Hasil tes siklus ketiga, diperoleh rata-rata hasil belajar 74,07 yaitu siswa yang mencapai KKM sebanyak 14 orang dengan persentase $100 \%$, sehingga semua siswa dalam siklus kedua ini tuntas dalam pembelajaran. Penelitian dihentikan pada siklus ketiga karena peneliti sudah memperoleh data bahwa hasil belajar siswa mencapai kriteria yang sudah ditentukan melalui penerapan model pembelajaran kooperatif tipe jigsaw dalam pembelajaran IPS kelas V semester II SD No. 2 Petandakan tahun pelajaran 2010/2011 yaitu sebanyak $100 \%$ siswa mencapai KKM 60.

Dari siklus pertama sampai siklus ketiga, siswa yang mencapai KKM mengalami peningkatan sebesar $28,57 \%$. Ini membuktikan bahwa hasil belajar siswa mengalami peningkatan dengan penerapan model pembelajaran kooperatif tipe jigsaw dalam pembelajaran IPS di kelas V semester II SD No. 2 Petandakan.Peningkatan hasil belajar siswa karena kerja keras dari siswa untuk bekerja sama dalam sebuah kelompok, saling membantu memberikan informasi dan pengetahuan yang dimiliki. Dari pihak peneliti dan guru selalu memberikan semangat dan memberikan penghargaan setiap kali siswa dapat menyelesaikan tugas-tugas dengan baik seperti memberikan pujian, tepuk tangan, acungan jempol, dan makanan kecil.Dengan demikian siswa menjadi tertarik dan senang belajar IPS serta merasa dihargai dan termotivasi untuk mengulangi perbuatannya. Hal ini akan membuat hasil belajar siswa dapat mencapai 
kriteria yang sudah ditentukan oleh sekolah.Berdasarkan hasil wawancara dengan beberapa siswa kelas $\mathrm{V}$ semester 2 SD No. 2 Petandakan mereka menyatakan bahwa mereka sangat senang belajar dengan menerapkan pembelajaran kooperatif tipe jigsaw. Hal itu dikarenakan mereka dituntut lebih aktif dalam pembelajaran sehingga pembelajaran dirasakan sangat menyenangkan dan tidak membosankan.

\section{Simpulan Dan Saran}

Berdasarkan pembahasan yang telah dikemukakan pada bab sebelumnya, maka dapat diambil simpulan sebagi berikut:Penerapan model pembelajaran kooperatif tipe jigsaw dapat meningkatkan hasil belajar siswa kelas V semester II SD No. 2 Petandakan. Pada siklus pertama sebanyak 10 orang siswa (71,43\%) mengalami tuntas belajar yaitu mencapai KKM 60 dengan rata-rata hasil belajar 62,64 sedangkan pada siklus kedua, siswa yang mengalami tuntas belajar sebanyak 11 orang siswa $(78,57 \%)$ dengan rata-rata hasil belajar 66,93 dan pada siklus ketiga, siswa yang mengalami tuntas belajar sebanyak 14 orang siswa $(100 \%)$ dengan rata-rata hasil belajar 74,07. Dari siklus pertama, kedua, dan ketiga diperoleh data bahwa hasil belajar siswa mengalami peningkatan sebesar 28,57\%. Jadi penelitian dihentikan pada siklus kedua karena kriteria keberhasilan siswa 100\% mendapat nilai minimal 60.

Berdasarkan simpulan di atas, disarankan hal-hal sebagai berikut. Guru hendaknya menggunakan strategi yang sesuai dengan kebutuhan peserta didik serta tidak selalu berpatokan pada metode pembelajaran konvensional.Guru hendaknya membiasakan peserta didik untuk memperoleh informasi selain dari buku paket yang tersedia dan selalu memecahkan masalah-masalah yang ada melalui diskusi kelompok.

Guru hendaknya menyediakan sumber belajar yang lain selain dari buku paket misalnya dari koran, artikel-artikel di internet serta buku-buku lain yang materinya terkait. PAIKEM agar siswa selalu bersemangat dan tidak jenuh dalam proses pembelajaran.Kepada peneliti lainnya diharapkan untuk melakukan penelitian lebih lanjut baik pada penerapan model pembelajaran kooperatif tipe jigsaw maupun pada model pembelajaran lainnya

\section{Daftar Pustaka}

Agung, A. A. Gede. (1997). Metodologi Penelitian Pendidikan. Singaraja: STKIP Singaraja.

------. (2005). Metodologi Penelitian Pendidikan. Singaraja: IKIP Negeri Singaraja.

Arnyana, Ida Bagus Putu. (2007). Strategi Belajar Mengajar. Singaraja: Undiksha

Hamalik, Oemar. (2004). Proses Belajar Mengajar. Jakarta: Bumi Aksara.

Ibrahim, Muslimin, dkk. (2000). Pembelajaran Kooperatif. Surabaya: University Press.

Kuntjojo. (2009). Model Pembelajaran Kooperatif. Tersedia pada http://ebekuntwordpress.com /2009/07/31/untitled/.diakses pada tanggal 22 Desember 2009.

Nurkancana, Wayan. (2007). Evaluasi Pendidikan. Surabaya: Usaha Nasional.

Raga, Gede, dkk. (2006). Konsep Dasar Ilmu Pengetahuan Sosial. Singaraja: Undiksha.

Raga, Gede. (2008). Buku Ajar Pendidikan Ilmu Pengetahuan Sosial di Sekolah Dasar.

Singaraja: Undiksha.Rusyan, Tabrani. (1989). Pendidikan Dalam Proses Belajar Mengajar. Bandung :Bina Budaya.

Sandiasih, Ni Luh. (2008). Penerapan Model Pembelajaran Kooperatif Tipe JigsawUntuk Meningkatkan Hasil Belajar Ilmu Pengetahuan Sosial Siswa KelasVII A Semester II SMP Negeri 2 Selat Karangasem Bali Tahun Ajaran2007/2008. Skrllmu Pengetahuan Sosiali (tidak diterbitkan). JurusanPendidikan ekonomi, Undiksha Singaraja.

Sudijono, Anas. (2007). Pengantar Evaluasi Pendidikan. Jakarta: PT. Raja Grafindo Persada.

Tjandra, Made, dkk. (2005). Pendidikan Ilmu Pengetahuan Sosial di Sekolah Dasar. Singaraja. Jurusan Pendidikan Dasar Fakultas Ilmu Pendidikan IKIPN Siangaraja.

Trianto. (2009). Mendesain Model Pembelajaran Inovatif-Progresif. Surabaya: Prenada Media Group.. 